\title{
(息)
}

Citation:

Lamond, I (2019) Leisure as an object of governmental policy in UK Elections: 1945 to 1983. Leisure / Loisir. ISSN 2151-2221 DOI: https://doi.org/10.1080/14927713.2019.1613170

Link to Leeds Beckett Repository record:

https://eprints.leedsbeckett.ac.uk/id/eprint/5757/

Document Version:

Article (Accepted Version)

This is an Accepted Manuscript of an article published by Taylor \& Francis in Leisure/Loisir on 8 May 2019, available online: http://www.tandfonline.com/10.1080/14927713.2019.1613170

The aim of the Leeds Beckett Repository is to provide open access to our research, as required by funder policies and permitted by publishers and copyright law.

The Leeds Beckett repository holds a wide range of publications, each of which has been checked for copyright and the relevant embargo period has been applied by the Research Services team.

We operate on a standard take-down policy. If you are the author or publisher of an output and you would like it removed from the repository, please contact us and we will investigate on a case-by-case basis.

Each thesis in the repository has been cleared where necessary by the author for third party copyright. If you would like a thesis to be removed from the repository or believe there is an issue with copyright, please contact us on openaccess@leedsbeckett.ac.uk and we will investigate on a case-by-case basis. 


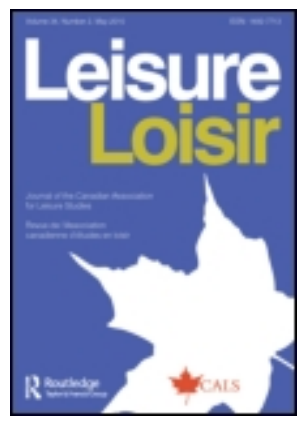

\section{Leisure as an object of governmental policy in UK elections: 1945 to 1983}

\begin{tabular}{|c|l|}
\hline Journal: & Leisure/Loisir \\
\hline Manuscript ID & RLOI-2018-0030.R1 \\
\hline Keywords: & $\begin{array}{l}\text { Leisure Policy, Elections, Manifestos, Lexical Analysis, the Imaginary of } \\
\text { Leisure }\end{array}$ \\
\hline Abstract: & $\begin{array}{l}\text { Following the Second World War, most working people, saw a substantial } \\
\text { change in both the amount of leisure time they had available and how it } \\
\text { could be enjoyed. During the 1950s the amount of paid leave that could } \\
\text { be taken had risen substantially which, coupled with a general increase } \\
\text { in basic disposable income, resulted in a growing demand for leisure } \\
\text { resources. It is in this period that we find the emergence of party } \\
\text { recognition of it as a legitimate arena for governmental policy. Using a } \\
\text { lexical frequency analysis this paper will consider how leisure was } \\
\text { construed as an object of governmental policy between } 1945 \text { and } 1983 . \\
\text { It concludes that such an approach affords us an opportunity to view } \\
\text { policy in general, and leisure policy in particular, in new ways, enabling } \\
\text { us to approach familiar topics from an alternative perspective. }\end{array}$ \\
\hline
\end{tabular}

\section{SCHOLARONE $^{\text {m }}$ Manuscripts}




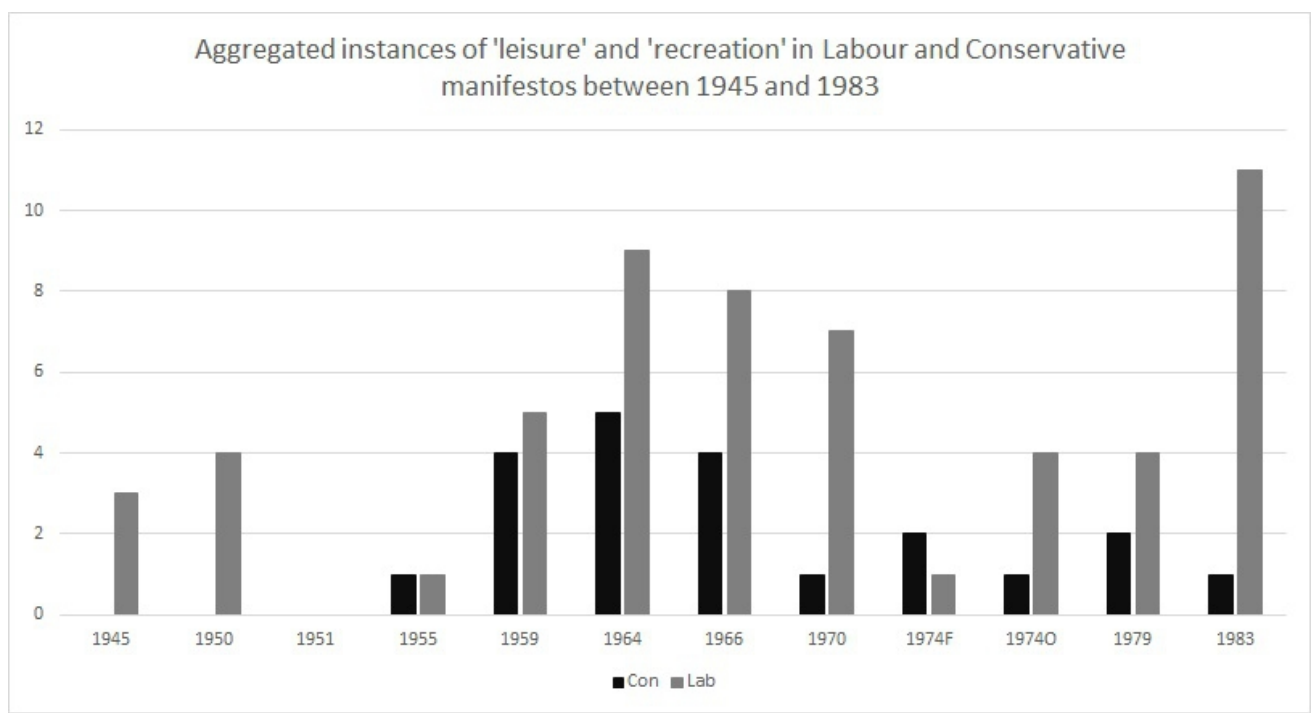

Figure 1: Aggregated instances of 'leisure' and 'recreation' in Labour and Conservative manifestos between 1945 and 1983

$171 \times 92 \mathrm{~mm}(120 \times 120 \mathrm{DPI})$ 


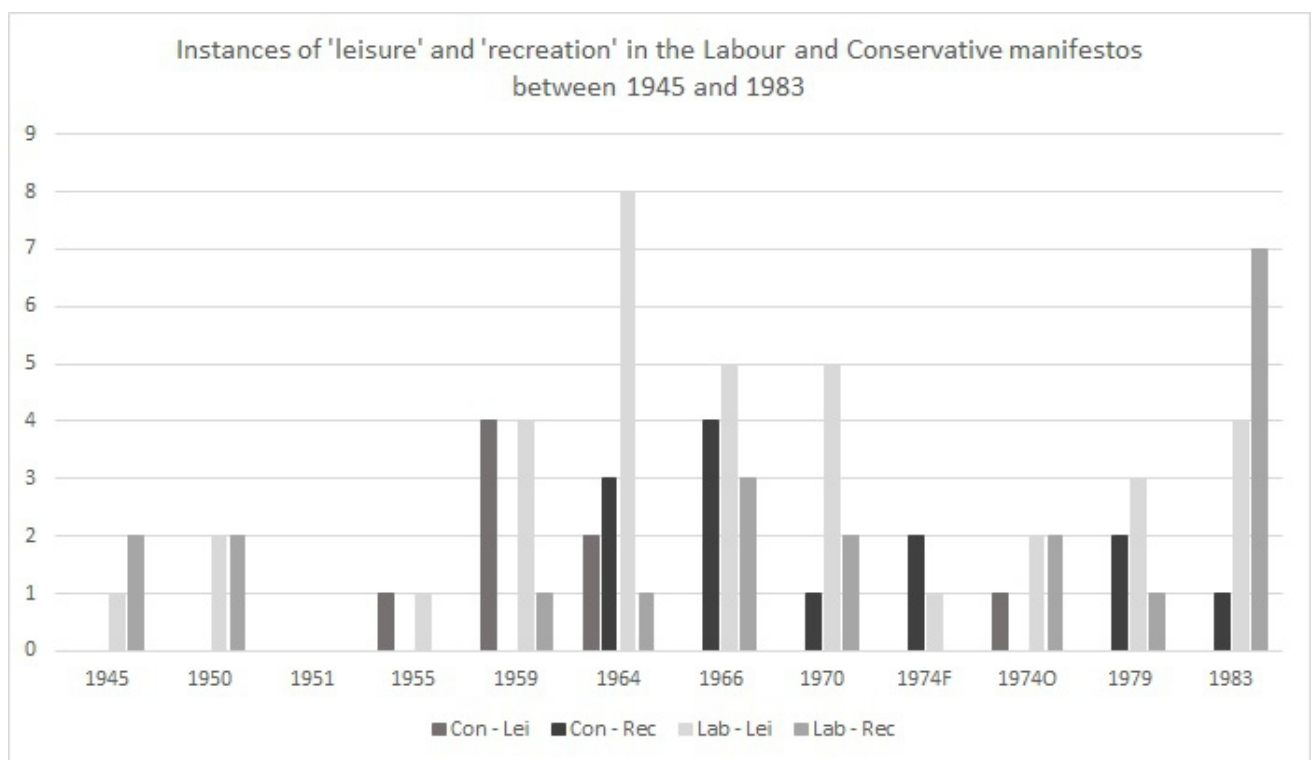

Instances of 'leisure' and recreation' in the Labour and Conservative manifestos between 1945 and 1983 $147 \times 85 \mathrm{~mm}(120 \times 120 \mathrm{DPI})$ 


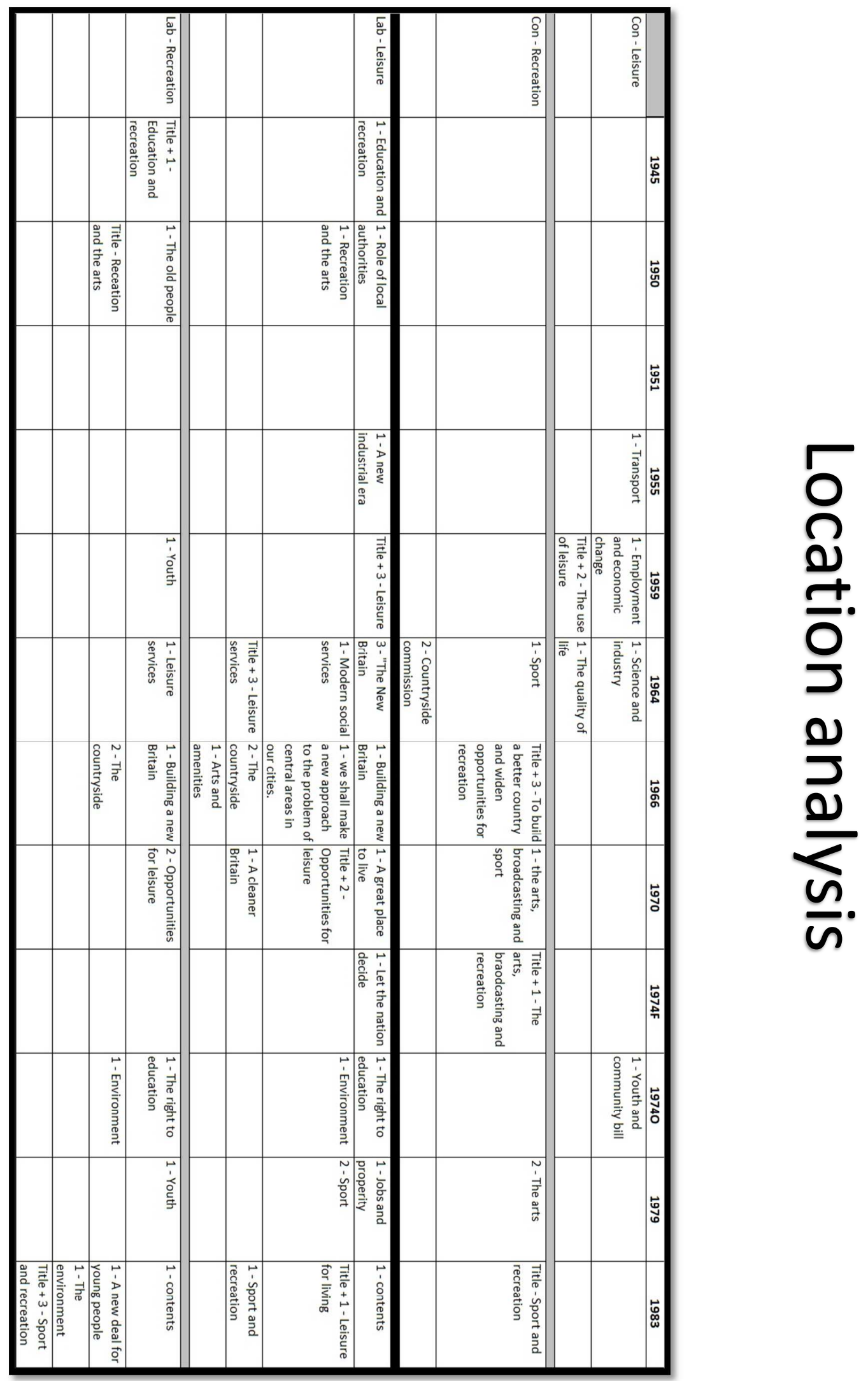




\section{Leisure as an object of governmental policy in UK election manifestos: 1945 to 1983} Lamond, I.

\section{Introduction}

In the eleven general elections of the Twentieth Century, prior to 1945, 'leisure' is only directly referred to twice in the manifestos of either the Conservative, Labour or Liberal party. Neither of those instances is associated with any explicit leisure policy. In the twelve elections that took place between 1945 and 1983 the words 'leisure' and 'recreation' occurs a total of 78 times; this would seem to suggest that 'leisure' is playing a more significant part in the political agenda in $\ominus$ f the election campaigns of that 38 -year period, than in the 45 years that they proceed. This does not equate to there being no political interest in leisure during the period up to 1945. There has been substantial commentary on the significance of leisure policy in national and regional government (such as Jones, 1986, and Parker and Ravenscroft, 1999) as well as the importance of leisure to the activities of political movements, particularly on the left (See, for example, Collette, 2003, and Snape, 2004). However, unlike such previous work, this paper focuses on the articulation of leisure as it occurs as an agenda item within the election manifestos produced for elections between 1945 and 1983. As such it offers an incremental contribution to a wider understanding of the relationship between governmental leisure policy and the electorate.

One approach to understanding governmental leisure policy would be to set out a definition of leisure, or at least a framework within which a conceptualization of leisure can be discussed at a policy level, and then seek to ascertain where such a topic is discussed within the policy discourse of a political party. Snape's (2017) recent contribution to something akin to this offers a fascinating and illuminating reflection on some of the work of John Stuart Mill, and its potential for establishing a way of considering leisure policy. Whilst Mill's construal of 
$\underline{\text { Utilitarianism does not conceive of leisure, per se, as being either morally good or otherwise, }}$ he does use it to construct a theory of leisure that valorises the social utility of what he conceives as the importance of refined forms of leisure. As Snape suggests, there are hints here of Eudemonia in Aristotle's conception of Eudemoniaethics; ; however, but in Mill's case the focus is on the social consequences of leisure. There are also resonances with Arnold and Ruskin, in that engagement in such leisure practices areis thought to result in improvements to the general well-being of society. This, Snape argues, suggestsHe suggests that while Mill is not “... while not-necessarily providing a conclusive resolution to all questions of leisure, [he]Mill... nevertheless provides a framework in which ([they])...can be debated" (p. 336). Whilst Although his argument is helpful and revealing, it still rests on developing inquiry that is, fundamentally, looking into policyin, from the a definition concieved outside a policy discourse. However, moving from a definition established outside a policysuch a discourse to a usage within it brings along with it tensions that can potentially jeopardise the inquiry. The political sociologist William E. Connolly (1974) has argued that many terms within political discourse are essentially contested. By setting out a definition, even if it is one that merely hints at a degree of universalism, risks turning a blind eye to a contestation that is central to the discourse to which it is being applied.

Such universalism in what constitutes leisure is not only absent in government, it is also missing within the field. As early as 1967, Voss suggested that a definition of leisure was urgently required, not just because of the profound economic changes that the post-war world had been through, but also because of "...the multi-disciplinary character of the concept itself" (1967, p.91). Debate has continued through the 1980s (Wilson, 1980 and Dumazedier, 1982) and 90s (Lee et al 1994), and, more recently, through the critical interdisciplinarity, complexity and 
nuance brought to the field with the theoretical orientations suggested by Rob Stebbins (2006) and Karl Spracklen (2014).

An alternative to looking from outside a discourse - in, is to look from within a discourse - out. Such an approach applied to leisure as an object of policy, as Sharpe's (2017) argument suggests, can move “...beyond talking about (leisure)...in broad and general terms, and instead recognize how leisure is historically, culturally, politically and socially situated" (p. 15). This changes the focus from a consideration of what constitutes 'leisure' and how it is then articulated in a policy agenda, to one that begins by asking how 'leisure' is being constructed as an object within a policy discourse. The aim of this paper is thus to consider how such imaginaries of 'leisure' and 'recreation' have been constructed within the political discourse of the Labour and Conservatives parties, as articulated in their manifestos, for general elections between 1945 and 19831. Giving attention to an analysis of 'leisure' as an artefact of its imaginary within a political discourse means this paper also differs from standard approaches to policy research, which tend to focus on either analysis of policy (its content), how policy arises (the process of policy formation), or the impact of its implementation (Weimer and Vining 2017). The importance of recognising anthe imaginary of leisure as an object of governmental policy, within a development of the histories of leisure, is that it can help us to gain insight into the discourses of leisure that have set the repertoire of recognised interaction, and the vocabulary of engagement, to which agents seeking governmental support for 'leisure' have had to cohere (Taylor 1997).

The shift to looking from a discourse - out, and from a consideration of how the imaginary of a policy domain constructs that domains object of attention, which is itself a move towards a more Foucauldian (1989) orientation, raises two subsidiary questions. First, are the political 
parties under investigation using the same, or similar, imaginary of 'leisure' as each other? There would seem no necessity for this to be the case. Consequently, party difference needs to be considered. Second, there would seem to be substantial grounds (thate historical, cultural, political and social situatedness to which Sharpe (2017) refers) for assuming the imaginary of 'leisure' will change over time. Such a perspective would warrant a review of how that imaginary-of 'leisure', within a political party, may also have changed. A subsidiary aim of this paper is thus to review those differences, between 1945 and 1983.

\section{Scope}

The question of scope falls into three parts: Wwhy the Conservative and Labour Party; why 1945 to 1983 , and why elections manifestos? I will deal with the first two here; the last will require a more detailed discussion and will therefore be handled separately.

In this paper the election manifesto texts of the Conservative and Labour Parties for UK general elections between 1945 and 1983 will be used as its source material. It draws on those two parties as they formed the two largest political groups within parliament during this period and, as a frame of reference, it is their policy priorities that came to dominate the policy agenda for the period under investigation.

Whilst the work of Jones (1986), Clarke \& Critcher (1985), and Snape (2004), amongst others, has made a significant contribution to our sociological understanding of leisure as part of political movements and, particularly, engagement with leisure in working class communities in the inter-war period and $19^{\text {th }}$ Century, 1945 has been identified as the start date because_as has already been argued, it marks the beginning of a period in which 'leisure' becomes drawn 
into the pelicy election agenda of parties that have gone on to form governments. It is also significant, as I will consider shortly, because of its importance in the study of UK manifesto texts. As an end date, 1983 marks the year of the first election after the period covered by the focus of this special issue, it will also be found to be a turning point after which direct reference to 'leisure' begins to decline. Whilst it re-emergeds as a theme from 1992 onwards, it was most commonly folded into a discussion that focused on heritage, culture and the creative industries. 1983 thus marks a natural point to pause and reflect.

\section{Election manifestos}

A party's manifesto is an aspirational document that not only sets out how a political organisation construes the setting to which their campaign is a response, but also indicates the way it intends to shape that setting in the future. It articulates the issues a party considers the most significant areas for debate during the election; areas that, they argue, need to be discussed now and acted on during the lifetime of the next parliament. Manifesto's, Budge (1994) argues, “...occupy a unique position as the only fully authoritative statement of the party policy for an election" (p455). As such they become the ideological point of reference for the organisation of each party's campaign (Lamond 2012) and the measure by which they will be held to account if elected into power.

Robert Peel, when he fought the seat for Tamworth in 1834, is credited as creating the first British election manifesto. That document was, however, a statement of a personal position and did not form part of a nationally co-ordinated campaign, overseen by a political party's central administration. For much of the Nineteenth century, through to the first half of the last, party leaders would construct an address to the public, principally circulated through the official party 
communication channels and the press (From 1924 this included election broadcasts on radio as well (Goddard 2001)), which outlined_, in very broad terms, the key position of the party= at the time of a general election. Although they frequently looked at current pressing concerns, and potential future approaches to addressing them, much of the leader's addresses would be retrospective; commonly in the form of an open letter to the voting public. According to Lang (1999), it was not until the second half of the Twentieth Century that we saw the election manifesto take on the role we attribute to it today

Elections form clearly defined historical moments that mark a period of possible transition. They are intense periods of time where the perspectives offered by different political parties are opened to public debate and contestation. Pronouncements made at elections reflect the way a political organisation construes the concerns of the electorate. They whilst offering a vision for the future which, the parties argue, could be secured if they were elected. They are complex events which produce a varied selection of materials across a wide range of media. If we take, as an example, the snap election of 2017 , the plethora of potential sources of information would include: party political broadcasts; billboard posters; candidates campaign leaflets; press releases; editorial columns; letters to the national press from party leaders, radio, television and press interviews; press reports; minutes of party meetings; Internet discussion forums; blogs, tweets, YouTube channels; emails to and from candidates, the vlogs of party leaders, press officers announcements and so forth. This melange of material represents the rich array of the party's policy positions to different audiences, accessing that information through different media. All these messages must be consistent and coherent to the party's declared position for the election. Any contradiction would result in eager broadcasters, journalistscommentators highlighting the party'sits inconsistency. What might be referred to as a consequent, or 
concurrent, secial-media storm creating substantial reputational, and potential campaign breaking, damage. (See, for example, Herzogenrath-Amelung, 2016, and Wynne-Jones, 2016)

It couldan be argued that manifestos communicate the position of a party only at the time specific historical moment of an election (Jones et al 2006), it is of little consequence outside that specific historical moment. Manifesto statements, such a position suggests, are merely a promotional device, produced for the sole purpose of securing powera vote. This is the argument that forms the basis of the commonly heard complaint that, once elected, parties never keep their promises. As a sentiment it suggests there is a disconnection between a party's electoral mandate, based on the declared policy intentions stated in their manifesto (Schumpeter 1943), and the policies they will pursue after being elected. Such a position ean, however, be ehallenged.is not consistent with empirical evidence.

Incorrect because sSeveral researchers (such as, Bara and Budge, 2001; Klemmensen et al, 2007) have shown there is a statistically significant connection between the policy statements presented in a party manifesto, and that party's policy position when in government. The Comparative Manifestos Project (CMP) is an ongoing research programme, part funded by the OECD (Organisation for Economic Cooperation and Development), that studies the relationship between election platform declaration and party priority in parliament. Drawing on data gathered from over 50 democracies, including Britain, the CMP has found a party's priorities in parliament, whether in power or opposition, are consistent with the positions they adopt during an election. There is an important distinction between a clear statement of implementing a specific policy which may go unmet and supporting policies that are broadly consistent with a party's policy position and priorities as outlined in their manifesto. Whilst the former undoubtedly occurs, the CMP suggests there is a statistically significant correlation 
connecting the later. That this paper's focuses on the imaginary of 'leisure' constructed in those election texts also means that the claim that governments never keep their promises is also, to an extent, irrelevant. However, the suggestion that the broad position and priorities suggestdeveloped byin the manifesto are more likely to be adhered to, reinforces the aim of examining the imaginary of 'leisure', and makes the articulation of policy world views (Kaal 2012) articulated during an election ${ }_{2}$ central.

A particular benefit of manifesto texts is that because they are a shared response to the pending election, political parties will be presenting their vision for the nation's future at the same time, and for the same purpose. Thus, the data they contain can be used comparatively, facilitating an assessment of how parties are constructing the imaginaries associated with policy priorities, at the same time. They offer a rare opportunity to synchronically examine a worked through world view presented by more than one political organisation. As Smith and Smith (2000) suggest, “...every manifesto positions its party in a discursive universe” (p468). It is of little concern whether or not those texts are read by the electorate, for the positions they declare are presented through a multi-platform array of sources, which are being consciously and unconsciously consumed by them throughout the election. Manifestos therefore provide a rich source of data about how the parties, contesting an election, locate themselves within the historical moment in which they are campaigning, and how they construct both their relationship to the electorate and that moment.

\section{Research approach}


To the extent that this inquiry is more interested in how anthe imaginary of 'leisure' is constructed within an electoral discourse, than in establishing the character of 'leisure' as any sort of thing-in-itself, the research philosophy adopted in this study is constructivist. To facilitate the identification of locations-where the most explicit articulations of the imaginary of 'leisure' is being articulatedare located in the texts, a two-step process was undertaken. By considering the imaginary from how 'leisure' and 'recreation' manifest in the context of the $\underline{\text { manifesto we work from inside the text out, rather than presupposing any characteristics of that }}$ imaginary prior to looking for how it is manifest in the text; i.e. from the outside - in.

First, each text was be subjected to simple scrutiny to identify 1) whether, or not, the terms "leisure" and "recreation" occur-within them, and 2) where they do-oceur, it established the frequency of their instance. In most comparative text analysis such frequency data is 'normalised'; i.e. the scale by which the frequency is measured is adjusted so that a clearer comparison can be made. This is commonly expressed as the frequency of instance within a given range, such as frequency per 1,000 words. This was not pursued in this case. Whilst the comparative frequency analysis of the use of either 'leisure' or 'recreation' can shed some light on its relative importance to other policy prioritiesthe party's full electoral program it tells us nothing about the imaginary of 'leisure' that is being constructed in the text. Simple frequency can, however, give us some trace evidence (Grésillon \& Perrin 2013, Visconti 2018legal_pragmatics) to indicate the importance-significance an agent, such as a political party, is placing on that imaginaryit as an object considered worthy of incorporation into its policy electoral agenda. Such a trace can suggest differences, when compared to that of another party, at the same election. $A$ further advantage is that such a base level analysis; 2 it can also support the next step of the process. 
The second step was to draw out those manifestos where we are more likely to discern how 'leisure' is being constructed as an object of governmental-policy interest. This meant looking at all instances and determining which were the bearers of thean imaginary-were. As an approach it echoes the analysis of the use of "democracy" in Farrelly's (2009) work on Labour manifestos between 1997 and 2005, and Bang's (2003) discussion of the connection between political communication and governance. Once identified, the texts were scrutinised to identify the imaginary of 'leisure' they contain. Being able to locate the instances of 'leisure' and 'recreation' also means it iwas possible to identify where those terms clustered. This was helpful ${ }_{2}$ as Meara's work on vocabulary networks (Meara 2016) suggests that such information can signpost us to places where an imaginary is being articulated most strongly.

The texts used were the digitised versions of the party manifestos made available through Richard Kimber's Political Science resources website (Kimber 2018). Whilst this made searching for terms easier it did mean that page numbering was lost. To confirm the accuracy of those texts other sources were established. For the text of Conservative and Labour Party manifestos up to October 1974 (the second general election in that year), FWS Craig's British General Election Manifestos: 1900 - 1974 was used (Craig 1975). For the elections of 1979 and 1983, the first two volumes of Iain Dale's collection of twentieth century manifestos (Dale 2000a, 2000b) performed the same role as that provided by Craig for earlier elections. However, these also meant pagination of the original was unavailable. Though incomplete ${ }_{2}$ some original copies of the manifestos were also accessed via the respective archives for the two parties: the Labour Party archive at the Peoples History Museum in Manchester, and the Conservative Party archive at the Bodleian Library in the University of Oxford. Please note that $Đ$ due to theis 
inconsistency around access to accurate pagination, references to the textuatmanifesto materiat texts will not include a page number.

Though this work represents an original inquiry its roots are in the author's doctoral research whilst at Sheffield Hallam University. The research is compliant with the ethies policy of that university, and the guidance on research ethics set out by the British Sociological Association.

\section{Examining the texts}

The instances of 'leisure' and 'recreation' within the Conservative and Labour Party manifestos between 1945 and 1983 can be illustrated in two graphs. Figure 1 illustrates the aggregate of instances of 'leisure' and 'recreation' in the manifestos for each party at all theeach elections between 1945 and 1983.

\section{[Insert Figure 1 near here]}

Aggregated instances of 'leisure' and 'recreation' in the Labour and Conservative manifestos between 1945 and $1983^{3^{*}}$

Figure one indicates that the instance of both terms is more frequent in the manifestos of the Labour Party than in those for the Conservatives. Also suggested is a shared absence of usage during the election of 1951 and a peak during that of 1964. Whilst the Conservative Party exhibit consistently low levels of instance between 1970 and 1983, those of the Labour Party,

\footnotetext{
"Please note that the abbreviations "Con" and "Lab" in figures 1 and 2 , refer to the Conservative and the

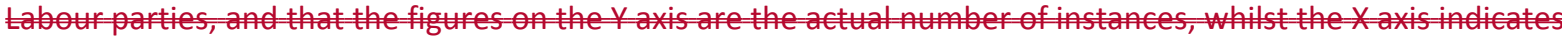

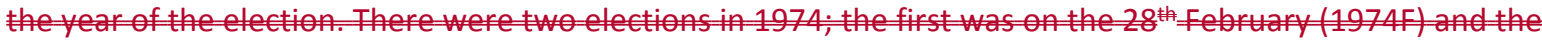
second on the $10^{\text {th }}$ October $(19740)$, hence the repetition of vears on that axis.
} 
over the same period, initially decline and then steadily rise to reach an overall peak in instance for the 1983 general election.

Figure 2 is rather more complex and nuanced than that of Figure 1. Whilst it Ecoversing the same period as Figure 1, it disaggregates the instances of 'leisure' and 'recreation'.

[Insert Figure 2 near here]

Instances of 'leisure' and 'recreation' in the Labour and Conservative manifestos between 1945 and 1983

Whilst the two terms ('leisure' and 'recreation') are taken to be connected, for the purposes of the frequency analysis, the difference in their emphasis may help us unpick some of the imaginary of 'leisure' being used.

If we begin with a consideration of the Conservative manifestos, we see the highest level of instance of 'leisure' occurring in 1959; the peak in the previous figure, observed in 1964, arising from the aggregation of the two terms. Other than a single instance in the election of October 1974, the three elections between 1955 and 1964 seem to be the only period in which the Conservatives explicitly use the term 'leisure'. From 1964 we can observe a preference for the term 'recreation' which, despite its absence in October 1974, occurs in their manifesto for every election from that date; with its highest level of instance occurring in 1966.

Turning our attention to the Labour Party: the period 1955 to 1970 would suggest that 'leisure' is the preferred term over 'recreation'. Peaking in 1964 it declines, though has an apparent stability, with slightly lower levels of instance during the elections of 1966 and 1970. Despite 
the sharper decline indicated by the single instance in the manifesto of February 1974, it seems to have experienced a resurgence in the elections that follow. The pattern of the instances regardingef 'recreation' in the-Labour manifestos is less straightforward. Other than 1945, 'recreation' has-most commonly been used less than 'leisure (though there are a few places where instances are equivalent - 1950; 1955; and 19740). However, that pattern is reversed in 1983 with the highest instance of 'recreation' by either Labour or the Conservatives for any of the preceding elections.

Having explored the findings uncovered by the first step of the methodology, the second step looks at the location of instances within each text. This contributes to understand the context in which those terms occur, and thus it helps to make more explicit the imaginary that is being articulated at those points. References to the countryside and parks, especially the National $\underline{\text { Parks, despite the strong connection between concerns around access to open space being of }}$ significant importance to political movements and activism on the left (a discussion of the historical significance of the right to roam, for example, in the Labour movement can be found in Smith, 1978, Parker and Ravenscroft, 1999, and Parker, 2006) was not directly considered. $\underline{\text { To do so would presuppose some character, or aspect, of the imaginary of leisure, i.e. it would }}$ have been an outside-in approach to discerning the imaginary of leisure being articulated ${ }^{4}$.

Figure 3 presents that location analysis. As with the other figures, the abbreviations "Con" and "Lab" have been used to represent the documents produced by the Conservative and the Labour parties; each term is separated by a grey line, and the two parties are divided by a black line. The election year is given on the first row. Each cell is either empty, to show the term does not appear, or list the number of instances within a section heading of the manifesto; this is in the format - " $\mathrm{n}$ - section heading". Where a term appears in a section heading, the number will 
follow the word "Title" and include the number of additional instance in the heading, excluding the title.

[Figure 3 near here]

Location analysis ${ }^{5^{*}}$

Beginning with 'leisure' in the manifestos of the Conservative Party. As a term it only occurs in multiple instances in 1959, where it appears twice in the section: "The use of leisure". The single instance that occurs in the section on Transport [1955 $\underline{6 * * *}^{*}$ seems to be a used in combination with "work" to argue that a quality transport infrastructure impacts every aspect of lifeeur lives. In a similar vein, there are also single instances in Employment and Economic Change [1959] and Science and Industry [1964]; in both these cases the focus is on technological change. In the party's manifesto for the election of October 1974, the lone appearance of 'leisure' is within a discussion around a broad review of "...existing arrangements in the field of housing, employment, leisure and advice services as they relate to young people" (Conservative Party, 1974. N. pags-).

Other than the cluster of instances in the section The Use of Leisure [1959] the lone occurrence of the term 'leisure' in the section A Quality of Life [1964] appears to be the only other instance where 'leisure' is being used to directly refer to an area of policy. That section opens with a suggestion that the diversity of activities associated with leisure has grown over recent history.

\footnotetext{
"As with the other figures, the abbreviations "Con" and "Lab" have been used to represent the documents produced by the Conservative and the Labour parties; each term is separated by a grey line, and the two parties are divided by a black line. The election year is given on the first row. Each cell is either empty, to show the term does not appear, or list the number of instances within a section heading of the manifesto; this is in the format - " $n$-section heading". Where a term appears in a section heading, the number will follow the word "Title" and include the number of additional instance in the heading, excluding the title.

*** The words in italic refer to the section heading of the party manifesto in which an instance, or instances, occur: square brackets "[...]" refer to the election year.
} 
Leisure is mostly associated there with an "appreciation of the arts"; "hobbies and handicrafts"; sport and travel: describing them all as "...a cheerful measure of rising prosperity" (Conservative Party, 1964. N. pag.). All of which are, they suggest, contributing to an enhanced quality of life.

The cluster of instances in the manifesto of 1959 within the section "The Use of Leisure" do not carry quite so forceful a presentation of leisure as an unalloyed benefit for all. Whilst it is at pains to argue that the "...welcome signs of the increasing enjoyment of leisure" are a result of the growth in general affluence it attributes to the party's policies, it does suggest that this has brought with it a challenge "...to make the growth of leisure more purposeful and creative, especially for young people" (Conservative Party, 1959. N. pag。).

As noted earlier, 'recreation' fares better than 'leisure' within the Conservative Party's electoral texts. In all cases 'recreation' is dominated by an association with sport and outdoor pursuits. In 1964 the focus was a recommendation that local authorities improve existing facilities and provide new resources; with playing fields, swimming baths and gymnasia being the targets highlighted in the manifesto. In 1966 greater attention was paid to the role of the proposed Coast and Countryside Commission in encouraging the "...growing numbers who leave the towns to sail, ski, climb, picnic or go caravanning" (Conservative Party, 1966. N. pag.). At subsequent elections attention hwas-been exclusively on the Sports Council $-\dot{\bar{\sigma}}-\underline{W}$ see little detail around what is to be delivered, but repeated suggestions that additional funding made available through the Sport Councilthat body will be made available ${ }_{2}$ to facilitate increased access to sport facilities across the country. 
In all instances the Conservative Party's position, across all its instances of 'leisure' and 'recreation' would appear to adopt a policy agenda that does not directly engage with leisure. In place of that they seek to recommend and encourage-and others to do so, either at a regional level, through local authorities, independent of central government, or nationally, through armslength bodies, such as the Sports Council $: \div$ both, to an extent, thought to be at arm's length from central government.

The use to which 'leisure' and 'recreation' are put in the Labour Party's manifestos is quite different. In the election texts ${ }_{2}$ both are most commonly used to refer to a governmental policy agenda that requires either direct intervention or, at the very least, working in partnership with others to deliver a more localised agenda. The location of 'leisure' in the party's policy landscape also shifts over time. In 1945 'leisure' and 'recreation' were drawn into a wider programme of cultural education across all ages. Through working co-operatively with local authorities, the party suggested people could "enjoy their leisure to the full" through having "opportunities for recreation" enabled by the provision of "...concert hall $[\mathrm{s}\}$, modern libraries, theatres and civic centres" (Labour Party, 1945- N. pag.). That theme continues into 1950, though it is supplemented with a short section that addresses proposals for supporting increased access to the countryside. Potentially indicative of how it identifies its core voters, the outdoor activities used to illustrate this, walking and cycling, do not seem to require the sort of personal financial investment mentioned in the examples of the Conservative manifesto of 1966 (such as sailing, skiing and caravanning)_and are the activities that were central to Labour, as a movement, rather than a parliamentary party, before 1945 (Jones, 1986; Collette, 2003; Snape, $\underline{2004)}$. 
During the elections throughout the 1950 s there seems to be a considerable overlap between the Conservative and Labour parties. Neither use either term in the documentation for the 1951 campaign. In 1955 both use 'leisure' once, and in a way that suggests the benefits of a stronger economy are being felt across the whole of life - not just in the workplace. In 1959, the parties diverge in how they see the state's role in managing leisure. The Conservatives emphasising the role of government as one that facilitates and encourages, while Labour returns to a focus on government's role in the delivery of national programmes or in working alongside others, at a more local level. The party's position on recreation and youth, however, seems close to that of the Conservatives; both suggesting that guided recreation is especially important for young people.

In their manifesto for 1964, 'leisure' and 'recreation' becomeare drawn into wider policy initiatives around the arts and culture. Their proposals include increased funding for out-door recreation facilities; development of parks and coastal areas; provision of youth centres and swimming pools; increased financial assistance for the arts, theatres, music, museums and galleries, independent film and television programme makers. It is, they argue ${ }_{2}$ the duty of Government "...to ensure that leisure facilities are provided and that a reasonable range of choice is maintained" (Labour Party, 1964. N. pag.). The purpose, according to the manifesto, would appear to be the creation a comprehensive Leisure Services; framing it as an extension of the welfare state, with echoes withechoing the party's planned comprehensive education programme (Initially outlined in its manifesto in 1955) and its creation of a National Health Service in 1945. It is of interest to note that after Labour's success at the 1964 election they appointed the first minister for the arts (Jennie Lee), whose remit included leisure. 
An imaginary of 'leisure', which sees it as part of a wider social and welfare program, is sustained in the 1966 manifesto. As with the previous manifesto, 'leisure' and 'recreation' occur across several policy areas within the text; however, in this case they are mainly single instances. Consequently, the focus is less intense than previously. A kinship with education and health is maintained, with links drawn to the former through the proposed establishment of a "University of the air", i.e. the Open University. With the latter, we find that instances cluster in the section "The Countryside", which is preceded by one headed "The family in the new welfare state" (Labour Party, 1966. N. pag.). In the text on the countryside there are 2 instances of both 'leisure' and 'recreation'. Where tThe imaginary there resonates with that seen in the single instances elsewhere in the manifesto ${ }_{2}^{-}$is in proposals for widening participation and access. That may be through proposed increases to investment in the provision of new amenities in towns and cities, in developing greater funding opportunities for national and regional organizations, or in the preservation of the coastline and common land.

In the 1970 election manifesto, 5 of the 7 instances of 'leisure' and 'recreation' (here as an element within the word recreational) occur within the one section: "Opportunities for leisure" (Labour Party, 1970. N. pag.). The two remaining single instances associate 'leisure' with what the party takes to be its achievements, whilst in government. Resonances with education or health are less overt here; with a policy of widening participation presented as part of the party's success.

1974 was a year of two elections; the first in February, which resulted in a Labour government with a 42-seat minority and fewer parliamentary seats than the Conservatives ${ }^{7 *}$, and the second

\footnotetext{
* In March 1974 Edward Heath failed to secure a coalition with the Liberal party. His lack of success led to him not being able to form a government; consequently, Harold Wilson was asked to become Prime Minister. The Labour partyLabour Party had secured 42 fewer elected MPs, i.e. parliamentary seats, than the Conservatives and Liberals combined.
} 
in October, where the party was still in a minority position - despite having the-morest seats in the House of Commons than any other party (Rallings and Thrasher 2009). In the manifestos, for both elections, the party referred to its previous successes within the areas of leisure policy, without advancing an imaginary of how that policy area should be understood. There remain links to education and leisure activities, but the reference is to what has been achieved, not what might be.

Reference to either 'leisure' or 'recreation' are also rather limited in the party's manifesto for the 1979 election, both being little more than a statement that there is a growing demand for leisure facilities and that a Labour government would commit to supporting the funding for them. In this, the party's commitment to leisure policy being aroundassociated with direct governmental involvement, or close partnership working in delivering local leisure outputs, indicates a difference to that of the Conservatives.

The Labour manifesto for the 1983 election echoes the breadth previously found in those for 1964 and 1966. "Leisure for living”, which occurs as a section heading ${ }^{8}$, covers 'leisure' at some length and takes its title from a Labour Party National Executive Committee (NEC) discussion document produced just before the 1959 election. Despite the resonances with those two previous elections, some of the language of the Conservative Party has begun to creep into Labour's text. The extension of the distance between government and policy delivery is hinted at through a declared commitment to strengthening arms-length bodies, whilst proposing the creation of new ones. Alongside familiar language of direct governmental engagement we start to see the party suggesting it plans to encourage or provide incentives for others to intervene. We also begin to see a more cautious approach to spending with suggestions that finances will be reviewed. So, whilst there appears to be a renewed vigour to Labour's imaginary around 
leisure policy, it is one that is beginning to borrow from an orientation that resonates with that of their rival.

\section{Considering context}

To fully establish the context in which the imaginaries of leisure outlined in the previous section emerge is beyond the scope of a single journal paper $\div$ : 5 Some initial discussion around this can be found in, for example, Clarke \& Critcher (1985) and Marwick (2003), with- Aa more thorough discussion ean be found in Henry (2001) or the collection of Bramham et al (2017). Despite that, an overview of the period can assist in deepening our understanding of the imaginaries that have been found.

The period following from the end of the Second World War to 1983 saw massive social, cultural and economic change for most people within the UK. The free time people had, the amount $\mathrm{it}_{\overline{5}}$ and their ability to control what could be done within that timeit, changed dramatically throughout the 1950s. In many households, income, and the average amount of paid leave working people were entitled to, was increasing (Dilnot 1988). For many, old models of employer managed leave were coming to an end (Price and Bain 1988). Overall, improvements in many people's financial situation had led the Labour MP Anthony Crosland to claim, “...affluence was guaranteed and mass unemployment probably over" (Crossland 1956, quoted in Morgan 2001, p157).

With more paid leave, a shorter working week, and greater disposable income (CSO 1971), how people chose to utilise their extra money and free time became of increased economic significance. Holiday camps flourished (Marwick 2003), and other forms of tourism 
experienced rapid expansion, as more people were spending a greater amount of time away from home (CSO 1971). The growth in average disposable incomes also led to an expansion in the market for consumer durables. Innovations in domestic appliances, together with the emergence of new forms of credit and finance, brought the purchase of many items, previously the preserve of the affluent, within the reach of many (Childs 1995). An increasing number of households, whether through hire purchase agreements or rental, were acquiring higher cost items such as televisions, fridges and washing machines (Rosen 2003). According to Abrams (1959) affluence in Britain was also disproportionately weighted towards the young, with real earnings for 15 to 25 -year olds increasing by $50 \%$ since 1938 ; double that for all other adults. These changes to consumer profile and purchasing behaviour also found expression in a growing demand for more ephemeral and life style items. According to Marwick (2003) this resulted in trends in fashion and music changing more rapidly, whilst converging to become a greater statement of the wearer's and listener's identity.

Just before the 1959 election, Conservative Party central office produced a discussion document "The Challenge of Leisure". One of the main concerns raised in this booklet is the apparent directionless character of young people's leisure time. Whilst its main conclusion was that the existence of suitable facilities and the adequate resourcing of leisure was essential to avoid the dangers of what it considered to be undirected leisure, it fell short of establishing how this could be achieved. That issue was addressed by the Bow Group. Shortly after the 1959 election two of its members, Richard Carless and Patricia Brewster (1959), wrote "The Patronage of the Arts". In it they argue for the societal value of leisure and the arts, suggesting that government, as an agent, must encourage others to provide the resources required. It is these arguments that inform the imaginary of 'leisure' found in the party's manifestos throughout the 1960s. Following the failure of the Conservatives party to form a government in either of the elections 
of 1974, leisure and recreation, more broadly, seem to fall out of favour. Whilst some discussion around leisure, principally as an aspect of cultural policy, continued within the party (for example, Money 1974, and St. John-Stevas 1978), it was not to achieve any renewed substance as a policy agenda until John Major's 1992 election campaign (Jefferies 2017).

In "The Challenge of Leisure", the Labour Party's NEC considered the recommendations of two publications for inclusion as policy at the 1959 party conference: "Learning for Living" (NEC, 1959a) and "Leisure for Living" (NEC, 1959b). It is these documents that set out the framework that was to form the foundations of the imaginary of 'leisure' found in the party manifestos of the 1960s. They establish a direct connection between leisure and learning; underpinned by direct government intervention at a national level and, locally, through partnerships enabled by governmental support of local authorities.

Despite the value of leisure to society, suggested in the Labour Manifestos between 1959 and 1970 , there is a profound decline in its part within the party's policy agenda throughout the remainder of the 1970s. That decline is also echoed in the manifestos of the Conservative Party. Tensions between Edward Heath's government and unions, around such issues as worker's rights and fair pay, seem to have refocused attention onto the workplace, and away from the place of recreation and leisure (Price and Bain 1988) in the first half of the decade. Following Labour's return to government, albeit with a minority, in 1974, those issues remained, ultimately driving the government (then led by Jim Callaghan) to financial support from the International Monetary Fund (IMF). The imposition of monetarist principles, required as part of the IMF's basis for supporting the UK, splitting the Labour Party and effectively creating the conditions that resulted in its downfall at the 1979 election (Hay 2010). 
In the four years that followed that defeat the Thatcher government engaged in a period of sustained confrontation with unions and the left (Thatcher 1994). During this time the Labour Party was riven with internal divisions (Shaw 1994). The principle opposition to the actions of central government emerging from Labour controlled Metropolitan Counties and boroughs, such as Manchester, Liverpool, Sheffield, Leeds and the Great London Council (Henry 1987, 2001). Whilst the party's manifesto of 1983 reflected the party's limited capacity to be effective as a force in parliament, it resonates with an awareness of what could be achieved at a local level (Gray 2000).

\section{Conclusion}

With regards to the history of leisure, the purpose of this paper has been to examine the construction of the imaginary of leisure, as it has been articulated in the election manifestos of the Conservative and Labour Parties, between 1945 and 1983. Through a close reading of those parts of the electoral texts where 'leisure' or 'recreation' occur as lexical items we have been able to discern how they have been constructedtheir construction as objects of governmental policy, at the time of a General Election. In doing so we have been able to grasp-incrementally extend our understanding of how dominant political agents within Britain have construed the relationship between leisure and the state from a novel perspective. Where most policy research carries with it a prerequisite to clarify the domain in which policy is to operate, this paper has replaced that with a question around how the domain constructs its object of interest. 
From the overview of the historical context presented, it became apparent that both the Conservative and Labour parties were drawn, in the years following the Second World War, into a consideration of developing policy around leisure because of profound changes taking place at a social, cultural and economic level in Britain. Both parties partook in internal debate around the value of leisure, producing several discussion papers intended to give steerage around the relationship between leisure and the state. We found that each parties' imaginary of leisure was articulated in salience with its broad ideological position. The construal of leisure emergent from the Conservative Party's manifestos was one that argued for minimal state engagement. Regarding leisure policy, use of incentives was proposed to encourage other agents to deliver on the objectives the party had identified. For the Labour Party there is an emphasis on direct state action, with a more localised agenda to be delivered through local government working in partnership with others. The imaginary of leisure in the Conservative Party was also found to be orientated towards the leisure pursuits and recreational activities in which a more middle-class public might choose to engage. Whilst increasing participation is seen as important, government (at a state and local level) are framed as facilitators rather than providers. This differed considerably from that presented by the Labour Party. Their construction of leisure, as an object of policy, was found to be more closely aligned with other state supported services, such as health and education. In place of encouragement we find a focus on the provision facilities and resources; with national and local government directly engaged in increasing access and participation.

Despite its peak in the 1960s, and subsequent decline, we found little change in the imaginary of leisure articulated by the Conservative Party in the period up to 1983 . The picture was somewhat different for the Labour Party. Despite a consistent position of direct intervention in the provision of facilities, funding and other resources, in the manifestos of the 1960s, concerns 
around the economy and the IMF's imposition of more monetarist economic principles, which had underpinned their financial bail-out for the UK in the 1970s, appears to have led to a decline in the party's interest in direct intervention as part of their imaginary of leisure, at a state level. Five years of minority government and a landslide Conservative victory at the 1979 election, seems to have moved Labour to an imaginary, at the level of state engagement, to one more closely aligned with that of thee Conservative Party. However, despite that the former imaginary appears to have shifted towards the metropolitan counties and boroughs rather than central government.

Through reviewing the imaginaries of 'leisure' articulated in manifesto texts, we have been able to ascertain an alternative trajectory for viewing the history of leisure's emergence as a policy objective; one that establishes the objects of investigation through their emergence within a discourse, rather than an approach that rests on establishing a discourse through identifying a pre-defined object. 


\section{$\underline{\text { References }}$}

Abrams, M. (1959) Social change in modern Britain. The Political Quarterly. 30, 149-156

Bang, H.P. (2003) Governance as political communication. In Governance as Social and Political Communication. Ed. H P Bang. (pp. 7-25) Manchester, Manchester University Press.

Bara, J., \& Budge, I. (2001) Party policy and ideology: Still new Labour. Parliamentary Affairs $54,590-606$

Bramham, P., Henry, I., Mommaas, H. \& van der Poel, H. (2017) Leisure and urban processes: critical studies of leisure policy in Western European cities. Abingdon, Routledge.

Budge, I. (1994) A new spatial theory of party competition: Uncertainty, ideology and policy equilibria viewed comparatively and temporally. British Journal of Political Science 24, $443-467$

Carless, R., \& Brewster, P. (1959) Patronage of the Arts: A Bow Group Pamphlet. London, Conservative Political Centre.

Castoriadis, C (1998 [1987]) The Imaginary Institution of Society. Massachusetts, MIT Press.

Childs, D. (1995) Britain Since 1939: Progress and Decline. Basingstoke, Macmillan.

Clarke, J.; Critcher, C. (1985) The Devil Makes Work: Leisure in Capitalist Britain. Basingstoke, Palgrave.

Collette, C. (2003). "Friendly spirit, comradeship, and good-natured fun": Adventures in socialist internationalism. International Review of Social History, 48(2), 225-244.

Connolly, W. (1974) The Terms of Political Discourse. Oxford, Blackwell Publishers.

Conservative PartyConservative PartyConservative Party Centre (1959) The Challenge of Leisure. London, Conservative Political Centre.

Craig, F.W.S. (1975) British General Election Manifestos: 1900 - 1974. London, Macmillan. CSO (1971) Social Trends No.2. (Ed.) M. Nissel. London, Her Majesty's Stationary Office. 
Dale, I. (2000a) Party General Election Manifestos 1900 - 1997: Vol. 1. The Conservative PartyConservative PartyConservative Party London, Routledge.

Dale, I. (2000b) Party General Election Manifestos 1900 - 1997: Vol. 2. The Labour PartyLabour Party. London, Routledge.

Dilnot, A. (1988) The Economic Environment. In A.H. Halsey (Ed.), British Social Trends Since 1900. Basingstoke, Macmillan Press.

Dumazedier, J. (1982) Social time, free time. Loisir et Societe. 5, 339-361.

Farrelly, M. (2009) Discourse and ideology: Democracy in the election manifestos of new Labour 1997 2005. 50th Political Studies Association Conference, University of Manchester 7th to 9th April 2009

Foucault, M. (1989) The Archaeology of Knowledge. Abingdon, Routledge.

Goddard, P. (2001) Political Broadcasting in Britain: System, Ethos and Change. In J. Bartle, \& D. Griffiths (Eds) Political Communications Transformed (pp. 111-130). Basingstoke, Palgrave Macmillan.

Gray, C. (2000) The politics of the art in Britain. London, Springer.

Grésillon, A., \& Perrin, D. (2013) Methodology: From speaking about writing to tracking text production. In E. Jakobs, \& D. Perrin (Eds) Handbook of Writing and text production, (pp.79-114). Berlin, Walter de Gruyter.

Hay, C. (2010) Chronicles of a death foretold: the winter of discontent and construction of the crisis of British Keynesianism. Parliamentary Affairs, 63, 446-470.

Henry, I.P. (1987) The Politics of Leisure and Leisure Policy in Local Government. Unpublished $\mathrm{PhD}$ thesis. Submitted to the University of Loughborough, 1987.

Henry, I.P. (2001) The Politics of Leisure (2 ${ }^{\text {nd }}$ Ed). Palgrave, Basingstoke. 
Herzogenrath-Amelung, H. (2016) The new instantaneity: how social media are helping us privilege the (politically) correct over the true. Media, Culture \& Society, 38(, pp.10801089

Jefferys, K. (2017) Sport and the Arts. In K. Hickson, \& B. Williams (Eds) John Major: An Unsuccessful Prime Minister? Reappraising John Major. N. Pag. London, Biteback.

Jones, B., Kavanagh, D., Moran, M., \& Norton, P. (2006) Politics UK (6th Ed). London, Longman.

Jones, S.G. (1986) Workers at Play: A Social and Economic History of Leisure 1918-1939. London, Routledge \& Kegan Paul.

Kaal, B. (2012) CDA and neuroscience: Cognitive maps of political discourse in the Netherlands. A lecture presented at the Language Ideology and Power Seminar, Lancaster University, 8th March 2012

Kimber, R. (2018) Richard Kimber's Political; Science Resources. Online at $<<$ http://www.politicsresources.net $>>$ Last accessed: $10^{\text {th }}$ June 2018

Klemmensen, R., Hobolt, S.B., \& Hansen, M.E. (2007) Estimating policy position using political texts: An evaluation of the Wordscore approach. Electoral Studies. 26, 746-755

Labour PartyLabour Party NEC (1959a) Leisure for Living. London, Labour PartyLabour Party.

Labour PartyLabour Party NEC (1959b) Learning for Living. London, Labour PartyLabour $\underline{\text { Party. }}$

Lamond, I.R. (2017) John Locke: Recreation, Morality and Paternalism in Leisure policy. In K. Spracklen, B. Lashua, E. Sharpe, \& S. Swain (Eds) The Palgrave Handbook of Leisure Theory. (pp. 249-270). London, Palgrave Macmillan. 
Lamond, I. (2012) Elections as Points of Discursive Contestation: Using a Critical Approach to Discourse as a Source of Empirical Data for Cultural Policy Studies. Critical Approaches to Discourse Analysis Across Disciplines, 5, 39-53

Lang, S. (1999) Parliamentary Reform, 1785 - 1928. London, Routledge.

Lee, Y., Dattilo, J., \& Howard, D. (1994) The complex and dynamic nature of leisure experience. Journal of Leisure research, 26, 195-211

Marwick, A. (2003) British Society Since 1945 (4th Ed). London, Penguin Books.

Meara, P., 2016. Texts as vocabulary networks. In H. Chodkiewicz; P., \& Steinbrich. (Eds) Working with Text and Around Text in Foreign Language Environments (pp. 193-204). Cham, Springer.

Money, E. (1974) The Conservatives and the Arts. Available via the Conservative PartyConservative PartyConservative Party Archive, Bodleian Library, Oxford.

Morgan, K.O. (2001) Britain Since 1945: The People's Peace (3rd Ed). Oxford, Oxford University Press.

Parker, G. (2006). The Country Code and the ordering of countryside citizenship. Journal of Rural Studies, 22(1), 1-16.

Parker, G., \& Ravenscroft, N. (1999). Benevolence, nationalism and hegemony: fifty years of the National Parks and Access to the Countryside Act 1949. Leisure Studies, 18(4), 297313.

Price, R., \& Bain, G.S. (1988) The Labour Force. In British Social Trends Since 1900: A Guide to the Changing Social Structure of Britain. (Ed.) A.H. Halsey. Basingstoke, Macmillan. Ralling, C., \& Thrasher, M. (2009) British Electoral Facts. London, Biteback Publishing. Rosen, A. (2003) The Transformation of British Life: 1950-2000. A Social History. Manchester, Manchester University Press.

Schumpeter. (1943) Capitalism, Socialism and Democracy. London, George Allen \& Unwin. 
Sharpe, E. (2017) Traditional theories of Leisure. In K. Spracklen, B. Lashua, E. Sharpe, \& S. Swain (Eds) The Palgrave Handbook of Leisure Theory. (pp. 13-18) London, Palgrave Macmillan.

Shaw, E. (1994) Crisis and Transformation-The Labour PartyLabour Party Since 1979. Abingdon, Routledge.

Smith, C. (1978) National Parks: Fabian Tract 456. London, Fabian Society.

Smith, C.A., \& Smith, K.B. (2000) A rhetorical perspective on the 1997 British party manifestos. Political Communications, 17, 457-473

Snape, R. (2004). The Co-operative Holidays Association and the cultural formation of countryside leisure practice. Leisure Studies, 23(2), 143-158.

Snape, R. (2017) John Stuart Mill and leisure. In K. Spracklen, B. Lashua, E. Sharpe, \& S. Swain (Eds) The Palgrave Handbook of Leisure Theory (pp. 325-338). London, Palgrave Macmillan.

Spracklen, K. (2013) Leisure, Sports \& Society. Basingstoke, Palgrave.

St. John-Stevas, N. (1978) The Arts: The Way Forward. Conservative Political Centre, London Stebbins, R. (2006) Serious Leisure: A Perspective for Our Time. Abingdon, Routledge.

Taylor, A. (1997) 'Arms-length but hands on'. Mapping the new governance: The Department of National Heritage and cultural politics in Britain. Public Administration, 75, 441-466 Thatcher, M. (1994) The Downing Street Years. London, Easton Press.

Visconti, J. (2018) Interpreting or in legal texts. In D. Kurzon, \& B. Kryk-Kastovsky (Eds) Legal Pragmatics. Amsterdam, John Benjamins Publishing.

Voss, J. (1967) The definition of leisure. Journal of Economic Issues, 1, 91-106.

Weimer, D.L., \& Vining, A.R. (2017) Policy analysis: Concepts and practice. $6^{\text {th }}$ ed. Abingdon, Routledge.

Wilson, J. (1980) Sociology of leisure. Annual Review of Sociology, 6, 21-40. 
Wynne-Jones, S. (2016) Flooding and media storms-controversies over farming and upland land-use in the UK. Land Use Policy. 58, 533-536.

\section{Manifestos directly referred to in text}

(NB: All texts used, were taken from Richard Kimber's political Science resources website: http://www.politicsresources.net)

Conservative Party (1959) The Next Five Years. Conservative Party, London.

Conservative Party (1964) Prosperity with Purpose. Conservative Party, London

Conservative Party (1966) Actions not Words: The New Conservative Programme. Conservative Party, London.

Conservative Party (1974) Putting Britain First. Conservative Party, London.

Labour Party (1945) Let us Face the Future. Labour Party, London

Labour Party (1955) Forward with Labour. Labour Party, London

Labour Party (1964) The New Britain. Labour Party, London.

Labour Party (1966) Time for Decision. Labour Party, London.

Labour Party (1974) Britain Will Win with Labour. Labour Party, London.

Labour Party (1979) The Labour Way is the Better Way. Labour Party, London.

\footnotetext{
${ }^{1}$ In this paper I use the word imaginary in a sense based on its conceptualisation in the work of Carlos Castoriadis (See Castoriadis 1998 [1987]). What Castoriadis refers to as the social imaginary are those practices and discourses that become embodied in social institutions, and through which an individual or group can become articulated. As such, an imaginary of leisure in policy becomes how leisure is construed as an object of concern to policy makers.

z It was only the Labour PartyLabour Party, before 1945, which consistently referred to their election document as the manifesto of the party, prior to that equivalent texts were more commonly a personal address from the party leader.

${ }^{3}$ Please note that the abbreviations "Con" and "Lab" in figures 1 and 2, refer to the Conservative and the Labour parties, and that the figures on the $Y$ axis are the actual number of instances, whilst the $X$ axis indicates the year of the election. There were two elections in 1974; the first was on the $28^{\text {th }}$ February (1974F) and the second on the $10^{\text {th }}$ October (19740), hence the repetition of years on that axis.

${ }^{4}$ Despite John Dower's report in 1945, to the Labour Party, on the Countryside and National Parks, there is very little consideration of this as an aspect of leisure in election manifestos. In the Labour and the Conservative Party manifestos of 1945 "park" does not occur. Countryside does not appear
} 
in the Labour manifesto of 1945, and only occurs once in that of the Conservative Party for that election. In that instance it forms part of a discussion around agriculture, and food provision. Other than the Labour Party's manifesto for 1950 (in which "Countryside" occurs five times) neither party, to any extent, associate parks or countryside, in their manifestos, in an association with leisure and recreation, except for the elections of 1959, 1964 and 1966. In those texts the link is overt and is covered elsewhere in the paper.

5As with the other figures, the abbreviations "Con" and "Lab" have been used to represent the documents produced by the Conservative and the Labour parties; each term is separated by a grey line, and the two parties are divided by a black line. The election year is given on the first row. Each cell is either empty, to show the term does not appear, or list the number of instances within a section heading of the manifesto; this is in the format - " $n$-section heading". Where a term appears in a section heading, the number will follow the word "Title" and include the number of additionat instance in the heading, excluding the title.

${ }^{6}$ The words in italic refer to the section heading of the party manifesto in which an instance, or instances, occur: square brackets "[...]" refer to the election year.

7 In March 1974 Edward Heath failed to secure a coalition with the Liberal party. His lack of success led to him not being able to form a government; consequently, Harold Wilson was asked to become Prime Minister. The Labour Party had secured 42 fewer elected MPs, i.e. parliamentary seats, than the Conservatives and Liberals combined.

8 The section heading is split into four sub-sections headed: The arts; Sport and recreation; The media; and Animal protection. As well as the heading, 'leisure' occurs in the sentence that introduces the four sub-sections as well as the part sub-headed: "Sport and recreation". "Recreation" occurs three times, other than in the sub-section title, in the section "Sport and recreation" 